\title{
Education quality, and teaching and learning in the post-2015 education agenda
}

\author{
Yusuf Sayed $^{\mathrm{a}, 1, *}$, Rashid Ahmed ${ }^{\mathrm{b}}$ \\ ${ }^{a}$ Cape Peninsula University of Technology, CPUT, South Africa \& Centre for International Education, University of Sussex, UK \\ ${ }^{\mathrm{b}}$ Department of Psychology, University of the Western Cape, South Africa
}

\section{A R T I C L E I N F O}

\section{Keywords:}

Teaching

Learning

Education quality

UNESCO

Development

Post-2015

\begin{abstract}
A B S T R A C T
At present, there is an intense and wide-ranging debate on the future of global development. This debate occurs in a context of increasing global inequality, global economic recession, conflict, and climate change. Discussions about the post-2015 education and development agenda in this context ambitiously seek to eradicate poverty, promote social and economic inclusion, tackle climate change, promote equity, and access to quality education. While the exact goals are not yet agreed and the shape of the final post-2015 development is still to be settled, there is a widespread consensus that education is priority and that equitable and quality education is core to the agenda. In this context, this paper discusses the continuities and discontinuities in the proposed post-2015 quality agenda through a textual analysis of UNESCO consultations on Education for All (EFA). In particular, this article focuses on the UNESCO post2015 position paper and the Muscat Global Education meeting agreement in April 2015. They are significant policy texts as they evidence the current global education discourse on education and the development agenda and reflect the broad consultations and thinking reflected in the thematic consultations. They also are important as they seek to clarify and secure the focus on the Education for All goals within a future post-2015 development agenda. The analysis of these texts pays particular attention to how quality is conceptualised in these texts, how it is translated into targets and how teachers are located in the global education quality discourse. The paper argues that while potentially broad conceptualisations of quality emerge from these texts, quality is still being defined as literacy and numeracy and still being constrained by what can be measured. While teachers are identified as crucial to the quality agenda, there is still a failure to engage more broadly with teaching and learning as well as the diverse contexts of teaching and learning. The article argues that what is needed is a continued foregrounding of quality as a dynamic, process oriented social justice endeavour to give effect to a holistic and comprehensive approach to the broad quality agenda.
\end{abstract}

(c) 2014 Elsevier Ltd. All rights reserved.

\section{Introduction}

At present, there is an intense and wide-ranging debate on the future of global development, which, in education, reflects the latest incarnation of the decade-long debate on education quality. This debate occurs in a context of increasing global inequality, global economic recession, conflict, and climate change. Discussions about the post-2015 education and development agenda

\footnotetext{
* Corresponding author at: Centre for International Teacher Education, Cape Peninsula University of Technology, Mowbray Campus, Highbury Road, Mowbray, Western Cape, South Africa. Tel.: +27 0219595832.

E-mail addresses: sayedy@cput.ac.za, y.sayed@sussex.a.cuk (Y. Sayed).

${ }^{1}$ Tel.: +44 01273872876 .
}

ambitiously seek to eradicate poverty, promote social and economic inclusion, tackle climate change, promote equity, and provide access to quality education.

In this context, this article discusses the continuities and discontinuities in the quality agenda through an analysis of the treatment of education quality in two UNESCO policy texts: the UNESCO Position Paper on Education Post-2015 (UNESCO, 2014a) and the 2014 GEM Final Statement: The Muscat Agreement (UNESCO, 2014b). Specifically, the article examines the underlying assumptions in the documents about the notion of education quality, how this translates into learning goals and targets, and what this implies for teachers. The analysis is illuminated by examples focused on South Africa, building on previous work conducted by the authors.

The article begins with a selective review of the literature on education quality to establish its conceptual framework. It then 
focuses on some of the processes and ownership of the post-2015 education agenda. A descriptive overview of the two policy texts is provided next, followed by the conceptualisation of education quality, particularly as it emerges in the defined goals, and the implications and consequences for the quality agenda through its operationalisation in the targets and the role of teachers outlined in the documents.

\section{Framing education quality}

Among the EFA goals agreed upon in Dakar in 2000 (UNESCO, 2000), Goal 6 focuses on education quality. Whilst it has not featured prominently in the MDG framework, the EFA Global Monitoring Report (GMR) has, over the years, attempted to monitor progress towards this goal. To that end, the GMR developed in its 2004/2005 report (UNESCO, 2005) a framework for education emphasising the need to complement access with quality in the global education agenda. The report acknowledges the contestation and complexity around defining quality and identifies two interrelated aspects of its framework. First, cognitive achievement is defined as a major objective of all education systems. The second is a notion of quality as encompassing values and creative and emotional development. The objectives that underpin the framework are identified as respect for individual rights, improved equity of access and of learning outcomes, and increased relevance (UNESCO, 2005: 19). The framework for quality that is developed (see Fig. 1, below) identifies the following core dimensions: learner characteristics, context, enabling inputs, teaching and learning, and outcomes.

Whilst this framework is widely cited, the notion of education quality underpinning it remains contested (Alexander in the current special issue, Sayed and Ahmed, 2011; Sayed, 1997; Tikly and Barrett, 2009). Nikel and Lowe (2010) suggest that the framework draws from the school effectiveness literature and conceives of quality within an input-output approach. Instead, they propose a dimensional model drawing on the fabric metaphor, and suggest that quality is a complex interaction between sometimes competing and complementary dimensions. Nikel and Lowe (2010) add responsiveness and reflexivity to the dimensions identified by Barrett et al. (2006), namely, effectiveness, efficiency, equality, relevance, and sustainability.

Tikly and Barrett (2009) further expand on the conceptualisation of education quality by drawing on Fraser and Sen. The social justice approach to education quality considerably expands on the human capital and human rights emphasis present in the GMR model. What is of importance here is the extent to which equity, participation, and diversity are present in the conceptualisation of quality. This article draws from these conceptualisations in the analysis of the post-2015 education agenda as articulated in the policy texts of UNESCO.

While equity and equality are argued to be central to the education quality agenda, Espinoza (2008) and Sayed (2014) argue that often the concepts are not clearly articulated or are used interchangeably. While the debate is extremely complex, in this article, 'equality' refers to sameness and equal opportunity. In contrast, 'equity' and 'inequity', in the context of this article, refer to issues of justice and injustice and posit that differential treatment may be required to achieve fairness and equal outcomes. In education policy, this suggests an approach that acknowledges the need for differential allocation of resources and treatment to achieve equity and quality. Equity conceived in this way further extends and develops the notion of education quality used in this article.

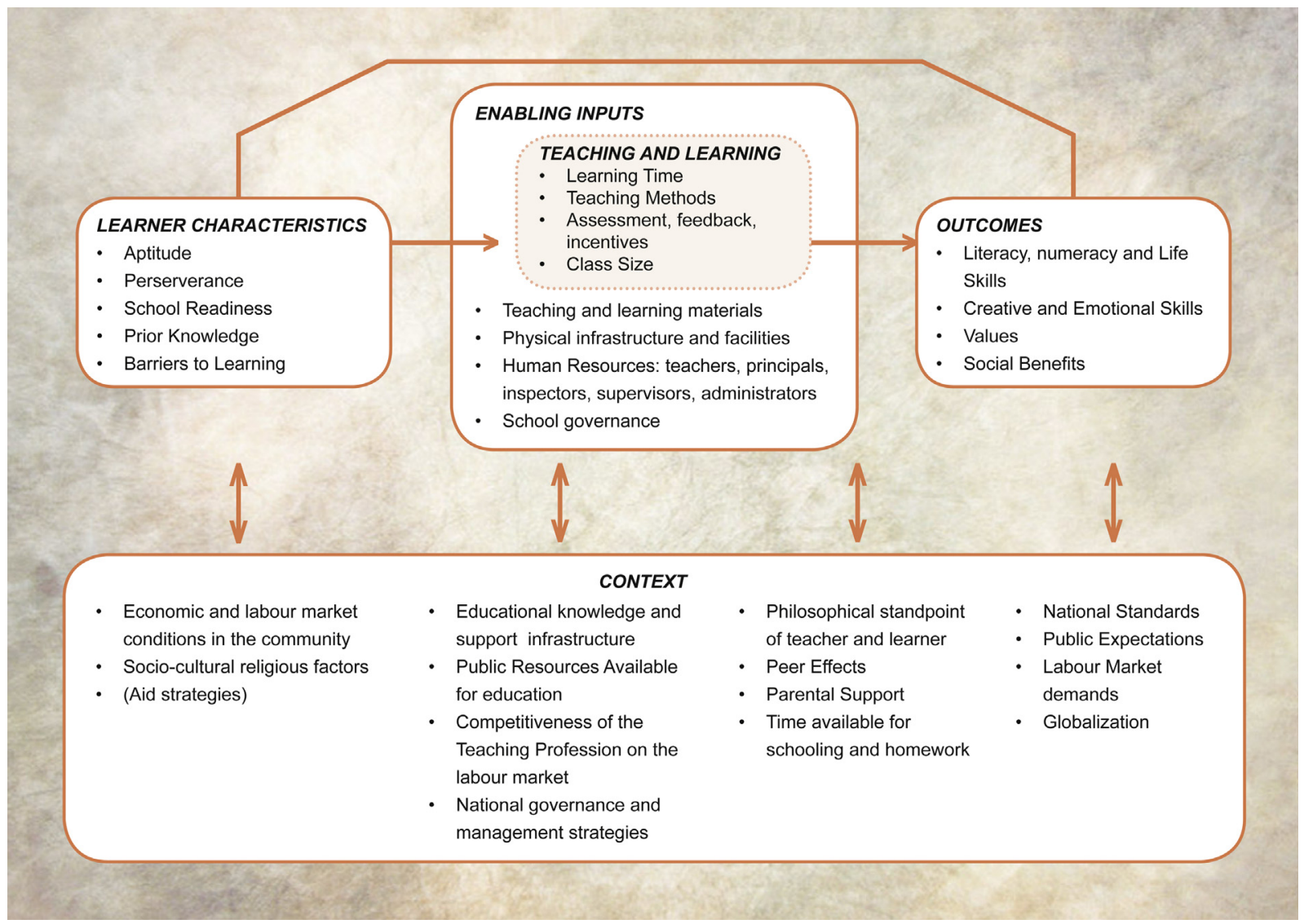

Fig. 1. A framework for understanding education quality. Source: UNESCO (2005). 
This article views education policy as more than simply a set of guidelines to guide educational interventions. Jones (2013) suggests that policy could be identified as text, as value-laden exercises, as discourses and as practice, inviting attention to underlying assumptions and agendas. Rizvi (2006: 198) points out that policy formulation is a dynamic, value-laden contested, process full of '. . struggles, compromises ...' and reflect the ' $\ldots$ authoritative allocation' of values. This is a particularly pertinent exercise in relation to policy literature on educational quality, a defining term within global agendas over the past decade but one whose meaning is nevertheless frequently elusive and multifaceted.

Drawing on a policy analysis framework, this article analyses the UNESCO Position Paper on the Post-2015 Agenda (UNESCO, 2014a) and the Muscat GEM agreement (UNESCO, 2014b). ${ }^{2}$ While acknowledging the complexities in policy formulation, the focus of this article is an examination of the extent to which global policy can, in spite of this complexity and contestation, advance the educational quality agenda and a proposal of what is needed at this juncture to shape this process.

The next section reflects on the consultation process in creating the post-2015 education agenda, then moves on to a close analysis of the textual construction. This process, which has, by all accounts, been far more extensive and far-reaching than the 2000 EFA and MDG processes, raises some issues which warrant attention, as the next section discusses.

\section{Contextualising the post-2015 education and development process: consultation and ownership of the process}

The post-2015 education and development discussion that seeks to lay a global framework for education includes several interrelated processes. These include the United Nations Development Group (UNDG), chaired by the United Nations Development Programme (UNDP), leading a 'global conversation' on post-2015 including about 100 national consultations and 11 global thematic consultations. The overall global thematic consultation on education is co-led by United Nations International Children's Emergency Fund (UNICEF) and United Nations Educational, Scientific and Cultural Organization (UNESCO), with support from the Government of Canada, the Government of Germany, and the Government of the Republic of Senegal. Most recently, the UNDG released the report of its consultations entitled A Million Voices: The World We Want: A Sustainable Future with Dignity for All (UNDG, 2015). The education consultation also includes UNESCO conversations about the post2015 education agenda and Education for All (EFA), including the UNESCO Position Paper on Education Post-2015 (UNESCO, 2014a) and the UNESCO Muscat Global Education Meeting (GEM) Agreement (UNESCO, 2014b). The second involves the UN High Level Panel Report (UN High Level Panel, 2013) entitled A New Global Partnership: Eradicate Poverty and Transform Economies through Sustainable Development. The third includes the work of the Open Working Group on Sustainable Development, which started officially at the Rio+20 conference in 2012 and released its Outcomes Document in July 2014 (http://sustainabledevelopment.un.org/owg. html). The same group has released a draft of Proposed Goals and Targets on Sustainable Development (http://sustainabledevelopment. un.org/content/documents/4523zerodraft.pdf). ${ }^{3}$ The fourth involved UNESCO-driven consultations about the post-2015 education agenda in relation to the EFA goals, which is the focus of this

\footnotetext{
${ }^{2}$ These two documents are discussed extensively throughout the article; we have spared the reader repeated citations of the documents with every mention.

3 This article does not analyse, as indicated, all the different processes and reports. However, it is important to note that the OWG Outcomes Document includes a target for teachers which is by '2030 increase by $x \%$ the supply of qualified teachers, including through international cooperation for teacher training in developing countries, especially LDCS and SIDS'.
}

article. Over and above these processes, numerous NGOs, think tanks, donor agencies, private sector foundations, and regional associations have released position papers on the post-2015 education agenda. ${ }^{4}$

All the reports and public discussions on the post-2015 education agenda agree that education is important, that education should be core to any future development framework and that education quality is central to education change and transformation. They also argue, with different degrees of emphasis, for a more expansive view of education beyond providing basic literacy and numeracy (King, 2013a,b). While the formulations of goals in the various documents vary slightly, the overarching goal 'Equitable and Quality Lifelong Learning for All' which emerges from the UNESCO and UNICEF education thematic consultations has received wide consensus and captures the essence of the conversation to date (Sayed, 2013). ${ }^{5}$ The importance of education is underscored by the online My World survey, where the majority of people voted for a good education as one of the most important aspirations for a post-2015 future (My World, 2013).

When reviewing the global education discourse attention should be paid to who sets the global agenda. There have been efforts to hold widespread consultations and processes such as the online thematic consultations and meetings with national governments (UNESCO and UNICEF, 2013). However, it is not always clear how widespread these consultations really are. In their analysis of the consultation process thus far, King and Palmer (2013) argue that it is largely driven by powerful Northern actors and question whether the global agenda is based on equal global participation. They point to the very limited interest expressed by many countries in the global South, including larger countries like China and Brazil. They suggest that Southern consultation can often be Northern-led and that the primary interest group may be stakeholders connected to overseas financial aid.

We highlight two crucial issues related to participation as a central dimension of quality. First, participation is not simply about greater involvement by the Global South, but also which Southern voices are heard. While there are certainly structural limitations to how extensive the consultations can be, it is crucial to foreground whether the global agenda is 'for' rather than 'with' the marginalised. Even the consultations from the Global South probably represent a particular 'privileged' constituency already well-resourced and connected to a global policy community. Second, participation is intimately connected to accountability. The symbolic power of global education discourse to mobilise constituencies for a future common agenda is unlikely to be realised if the uneven processes of participation also reflects a lack of ownership and accountability.

One of the biggest challenges in the transformation of South African education has been the contradiction between the discourses of participation in policy documents, and the absence of substantive participation by all education stakeholders. This top-down policy initiative further exacerbated the processes of educational exclusion in South Africa, especially for the marginalised (Sayed and Ahmed, 2011). Groups not substantially involved in policymaking, who do not feel ownership of the defined goals, may comply expressly to access donor funds or attempt to demonstrate the meeting of targets without investing efforts to transform all the education processes the goals imply. More

\footnotetext{
${ }^{4}$ See UNESCO and UNICEF (2013) for a review of some of the organisational positions on the post-2015 education agenda.

${ }^{5}$ For example, the High Level Panel Report formulates the overarching goal as 'Provide Quality Education and Lifelong Learning' while the Open Working Group on Sustainable Development identified the overarching goal as 'Ensure inclusive and equitable quality education and promote life-long learning opportunities for all'.
} 
importantly, the global education agenda may not accurately reflect the concerns of the most marginalised.

\section{Overview of the UNESCO policy texts}

Having contextualised the process in developing the post-2015 education agenda and some of the contestations, this section focuses on the analysis of the two UNESCO texts as key documents in setting forth an understanding of education for the post-2015 education and development agenda. The UNESCO EFA process, to a large extent, builds upon the UNICEF and UNESCO education thematic consultations and UNESCO-led discussions with member states to review and assess the EFA goals agreed on at Dakar in 2000 (UNESCO and UNICEF, 2013). They are significant policy texts, as they evidence the current global education discourse on education and the development agenda. The texts reflect and are consistent with the broad consultations and thinking reflected in the thematic consultations. They also are important as they seek to clarify and secure the focus on the EFA goals within a future post-2015 development agenda. Moreover, they reflect how international agencies and their constituencies position themselves in a future development framework.

There are both continuities and discontinuities in the two UNESCO policy documents, analysed in greater detail in subsequent sections. However, to contextualise the discussion, this section first provides a brief overview of the texts, identifying some of the more important shifts and changes between the position paper (UNESCO, 2014a) and the Muscat GEM agreement (UNESCO, 2014b).

The position paper (UNESCO, 2014a) is a detailed policy text outlining UNESCO's position on the post-2015 education agenda, including its vision and guiding principles as well as its overarching goal. The overarching goal 'Ensure equitable quality education and lifelong learning for all by 2030' is operationalised in the document through a discussion on priority areas, each including a rationale, targets and exemplar indicators.

The position paper begins by articulating the link between education and development and provides a detailed motivation for the contribution education can make to development. Education, it is argued, can play a role in achieving 'social well-being, sustainable development and good governance', can promote 'peace and social cohesion' and be responsive to diversity. This document also provides a motivation for a single stand-alone goal as well as the necessity to include education in other development goals. The position paper articulates a very broad vision of education, emphasising the fundamental principles that should shape the future agenda by affirming education as a fundamental human right and a public good and reaffirming a humanistic and holistic vision of education as essential to personal and socioeconomic development.

Targets for six different priority areas are identified in this paper: for basic education, post-basic and tertiary education, youth and adult literacy, skills for work and life, quality and relevant teaching and learning, and financing of education. Two targets are identified for each priority area except for basic education and youth and adult literacy, which each have one target. Detailed exemplar indicators are provided, both in the text and in Table 1.

The Muscat GEM agreement (UNESCO, 2014b) is a much briefer document and there are many differences from the previously described position paper. Vision and principles are again discussed, albeit more briefly, in a section called 'Vision, principles and scope of the post-2015 education agenda'. This document concentrates on the 'status of the EFA' which presents a brief review of the progress on EFA and reiterates the unfinished education agenda message. The document then identifies the overarching goal, which is formulated as 'Ensure equitable and inclusive quality education and lifelong learning for all by 2030' (UNESCO, 2014b: 3). There is a call for the goal to be translated into global targets, for which minimum global benchmarks and relevant indicators will be developed.

While the position paper (UNESCO, 2014a) details the education-development link, the focus of the Muscat GEM agreement (UNESCO, 2014b) is the unfinished EFA agenda. Though the latter still argues that 'education must be placed at the heart of the global development agenda', the how is missing in this paper. The Muscat GEM agreement is prefaced by references to some of the earlier processes and reports including the 2013/14 EFA Global Monitoring Report, but the position paper is not mentioned. Some of the fundamental principles covered in the position paper are reiterated, such as education as a human right. One significant exclusion of this paper is the commitment to 'education as a public good' which is present in the position paper. A concern not reflected in the position paper, but noted in the Muscat GEM agreement, is the 'increasing violence and attacks against children and personnel within the education institutions' (UNESCO, 2014b: 28). The detailed rationale for the targets presented in the position paper is not present at all in the Muscat GEM agreement.

The most significant shifts in the Muscat GEM agreement, some of which are explored later, pertain to the goal itself as well as the targets. Table 1 below lists the ten targets of the position paper and the seven targets of the Muscat GEM agreement. ${ }^{6}$ Target 1 in the position paper includes both basic education and at least one year of pre-primary education. In the Muscat GEM agreement this is expanded to two targets with a greater focus on pre-school education, defined as 'early childhood care and education' but still retaining, as a minimum, one year of free and compulsory education. The new targets also now include a reference to 'gender equality and the most marginalised'. The addition of 'particular attention to gender equality and the most marginalised' appears as a common ending statement to most of the targets (Targets 1, 2, 3 and 4).

The targets for transition to and completion of quality upper secondary education (Target 2), access to tertiary education systems (Target 3 ) and participation in continuing adult education and training programmes (Target 6 ) from the position paper are absent, and appear to be integrated into a more expansive target, formulated as 'By 2030 , at least $\mathrm{x} \%$ of youth and $\mathrm{y} \%$ of adults have the knowledge and skills for decent work and life through technical and vocational, upper secondary and tertiary education and training, with particular attention to gender equality and the most marginalized' in the Muscat GEM agreement (UNESCO, 2014b: 3). This expansive target also integrates the target (Target 5 ) that focused specifically on access to knowledge, skills and work for youth in the position paper.

While worded differently, a target for teachers (Target 7 ) in the position paper (UNESCO, 2014a) and Target 6 in the Muscat GEM agreement (UNESCO, 2014b) are core to the UNESCO position. The financing of education is also a target in both papers, though the two targets in the UNESCO position paper are replaced by a single one (Target 7) in the Muscat GEM agreement. A key absence resulting from this reduction is that the donor commitment to financing stated in the target in the UNESCO position paper is not included in the single target in the Muscat GEM agreement.

Depending on how the word 'learners' in Target 5 of Muscat GEM agreement (UNESCO, 2014b) is interpreted, this target and Target 8 of the position paper are similar. Overall, the ten targets of

\footnotetext{
${ }^{6}$ The targets from the two texts are presented alongside each other, with the targets that seem to be similar placed in the same row. The more important changes pertinent to this article are highlighted.
} 
Table 1

Comparison of the ten targets of the Position Paper on Education Post-2015 (UNESCO, 2014a) and the seven targets of the Muscat GEM agreement (UNESCO, $2014 \mathrm{~b}$ ).

\begin{tabular}{|c|c|}
\hline Position Paper on Education Post-2015 & The Muscat GEM Agreement 2014 \\
\hline $\begin{array}{l}\text { Target 1: All children participate in and complete a full cycle of free, } \\
\text { compulsory and continuous quality basic education of at least } 10 \text { years, } \\
\text { including } 1 \text { year of pre-primary education, leading to relevant and } \\
\text { measurable learning outcomes based on national standards. }\end{array}$ & $\begin{array}{l}\text { Target } 1 \text { : By } 2030 \text {, at least } \mathrm{x} \% \text { of girls and boys are ready for primary school } \\
\text { through participation in quality early childhood care and education, including } \\
\text { at least one year of free and compulsory pre-primary education, with particular } \\
\text { attention to gender equality and the most marginalized. }\end{array}$ \\
\hline $\begin{array}{l}\text { Target 2: Increase transition to and completion of quality upper secondary } \\
\text { education by } \mathrm{x} \% \text {, with all graduates demonstrating relevant learning } \\
\text { outcomes based on national standards. }\end{array}$ & $\begin{array}{l}\text { Target } 2 \text { : By } 2030 \text {, all girls and boys complete free and compulsory quality basic } \\
\text { education of at least } 9 \text { years and achieve relevant learning outcomes, with } \\
\text { particular attention to gender equality and the most marginalized. }\end{array}$ \\
\hline $\begin{array}{l}\text { Target 3: Tertiary education systems are expanded to allow qualified } \\
\text { learners to access and complete studies leading to a certificate, } \\
\text { diploma or degree. }\end{array}$ & $\begin{array}{l}\text { Target 3: By } 2030 \text {, all youth and at least } \mathrm{x} \% \text { of adults reach a proficiency level in } \\
\text { literacy and numeracy sufficient to fully participate in society, with particular } \\
\text { attention to girls and women and the most marginalized. }\end{array}$ \\
\hline $\begin{array}{l}\text { Target } 4 \text { : All youth and adult achievement literacy, numeracy and other } \\
\text { basic skills at a proficiency level necessary to fully participate in a given } \\
\text { society and for further learning. }\end{array}$ & $\begin{array}{l}\text { Target } 4 \text { : By } 2030 \text {, at least } \mathrm{x} \% \text { of youth and } \mathrm{y} \% \text { of adults have the knowledge and } \\
\text { skills for decent work and life through technical and vocational, upper } \\
\text { secondary and tertiary education and training, with particular attention to } \\
\text { gender equality and the most marginalized. }\end{array}$ \\
\hline $\begin{array}{l}\text { Target 5: Increase by } \mathrm{x} \% \text { the proportion of youth (15-24 years) with relevant } \\
\text { and recognized knowledge and skills, including professional, technical and } \\
\text { vocational, to access decent work. }\end{array}$ & $\begin{array}{l}\text { Target 5: By 2030, all learners acquire knowledge, skills, values and attitudes to } \\
\text { establish sustainable and peaceful societies, including through global } \\
\text { citizenship education and education for sustainable development. }\end{array}$ \\
\hline $\begin{array}{l}\text { Target 6: Increase by } \mathrm{x} \% \text { participation in continuing adult education and } \\
\text { training programmes, with recognition and validation of non-formal } \\
\text { and informal learning. }\end{array}$ & $\begin{array}{l}\text { Target 6: By 2030, all governments ensure that all learners are taught by } \\
\text { qualified, professionally-trained, motivated and well-supported teachers. }\end{array}$ \\
\hline $\begin{array}{l}\text { Target 7: Close the teachers' gap by recruiting adequate numbers of } \\
\text { teachers who are well-trained, meet national standards and can } \\
\text { effectively deliver relevant content, with emphasis on gender balance. }\end{array}$ & $\begin{array}{l}\text { Target 7: By 2030, all countries allocate at least } 4-6 \% \text { of their Gross Domestic } \\
\text { Product (GDP) or at least } 15-20 \% \text { of their public expenditure to education, } \\
\text { prioritizing countries most in need; and strengthen financial cooperation for } \\
\text { education, prioritizing countries most in need. }\end{array}$ \\
\hline \multicolumn{2}{|l|}{$\begin{array}{l}\text { Target 8: All young people and adults have opportunities to } \\
\text { acquire - supported by safe, gender-responsive and inclusive } \\
\text { learning environments-relevant knowledge and skills to ensure } \\
\text { their personal fulfilment and contribute to peace and the creation } \\
\text { of an equitable and sustainable world. }\end{array}$} \\
\hline \multicolumn{2}{|l|}{$\begin{array}{l}\text { Target 9: All countries progress towards allocating } 6 \% \text { of their Gross } \\
\text { National Product (GNP) to education and } 20 \% \text { of their government } \\
\text { budget to education, prioritizing groups, most in need. }\end{array}$} \\
\hline $\begin{array}{l}\text { Target 10: All donors progress towards allocating at least } 20 \% \text { of their } \\
\text { Official Development Assistance (ODA) or its equivalent to education, } \\
\text { prioritizing countries and groups most in need. }\end{array}$ & \\
\hline
\end{tabular}

the position paper have been reduced to seven targets in the Muscat GEM agreement. ${ }^{7}$

\section{Unpacking the overarching goal in the policy texts}

While there is still debate about whether single or multiple goals are needed (UNESCO and UNICEF, 2013), the advantage of a single overarching goal with an emphasis on quality is that it succeeds in framing the post-2015 education agenda as a 'quality' agenda. Unlike the previous EFA goals, which separated the access and quality agendas, a single goal suggests that there is only one united agenda. Furthermore, though quality was stated previously as a goal among the EFA goals, the absence of clear targets for quality in the EFA goals may have served to delegitimise the quality agenda. The challenge now lies in how quality is conceptualised and operationalised. This section analyses these issues to unpack the notions of quality embedded within these documents.

The overarching goal specifies the notion of quality as 'equitable quality education' in the Position Paper on Education Post-2015 (UNESCO, 2014a) and as 'equitable and inclusive quality education' in the Muscat GEM agreement (UNESCO, 2014b). This is cemented by numerous references to equity in both documents. The position paper explicitly acknowledges that 'A focus on equity is paramount and particular attention should be given to marginalised groups' (UNESCO, 2014a: 3). Whether equity is positioned as a dimension of quality (Barrett et al., 2006; Sayed and Ahmed, 2011) or outside a definition of quality, is less relevant at this point. What is crucial is that the inclusion of equity substantially broadens the quality

\footnotetext{
${ }^{7}$ The rationale for shifts and continuities in target-setting between two papers is an aspect which warrants further research and is beyond the scope of the article to address.
}

agenda and is consistent with broad conceptualisations of quality (cf. Tikly and Barrett, 2009). The Muscat GEM agreement extends this even further with the reference to 'inclusive'. Both formulations are similar to the UNESCO and UNICEF education thematic consultations where the overarching goal is formulated as 'Equitable, Quality Education and Lifelong Learning for All' (UNESCO and UNICEF, 2013).

The formulation of the overarching goal to include the word quality for the post-2015 education framework is a significant achievement. It cements the quality turn and suggests that, in spite of the unfinished agenda, educational policy is not narrowly confined to physical access to schooling. It is an acknowledgement of some of the adverse consequences of the Millennium Development Goals (MDG) access agenda and provides the opportunity to hold all stakeholders accountable to the quality agenda. The focus on quality may be considered as not altogether new. Quality, it is argued, has long been part of the global agenda, dating back to Jomtien and Dakar (King, 2013a,b). While this is arguably true, it is evident that notwithstanding the commitment to quality in earlier global documents, the vision was reduced with the MDGs. Moreover, at Dakar, no clear and measurable targets for quality were set. Whether the lack of targets in past agreements is a result of policy omission or default, the consequence has been that the driver of the global agenda and the consequent policy attention and aid funding has been targeted to increasing physical access.

The reference to 'inclusive quality education' appears to be an attempt to emphasise quality as social justice. However, the use of inclusive quality education is somewhat ambiguous and contested, reflecting both a narrow (disability) and broader (all forms of exclusion) focus. Some definitions emphasise the focus on disabilities as captured in this definition, 'Inclusive education is the term used to describe educational policies and practices that 
uphold the rights of learners with disabilities to belong and learn in mainstream education' (Engelbrecht and Green, 2001: 4). The UNESCO position is much broader and captured as 'it is about being proactive in identifying the barriers and obstacles learners encounter in attempting to access opportunities for quality education, as well as in removing those barriers that lead to exclusion' (UNESCO, 2014d). Sayed and Soudien (2003: 11) point to the various ways in which these discourses have been appropriated. Of relevance here is the extent to which they may not include a focus on injustice and inequality. They argue that '... any research into ... exclusion should focus on the processes and rules through which inequality and injustice occur' and suggest that the binary usage of this terminology is not helpful, as inclusionary processes also exclude. More importantly, they argue that there are various forms of exclusion: race, class, gender etc. The complex relationship among these various forms of exclusion within the contexts of diverse societies should be included, they say, in conceptualisations of inclusion and exclusion.

\section{Education quality and learning in the policy texts}

The analysis thus far suggests that the articulation of equitable and inclusive quality as a goal cements the turn towards prioritisation of quality and frames its pursuit within a social justice perspective, consistent with the emphasis on education as a human right and as a public good. This is potentially a huge quality agenda. This section reviews how the potentially broader conceptualisation of quality evident in the goals and elsewhere in these documents is operationalised in terms of the targets, with a specific focus on learning.

There are multiple ways in which learning is articulated and concretised in the targets. In the Muscat GEM agreement, targets for learning are specified in relation to '... girls and boys are ready for primary school ...' (Target 1$), \ldots$ girls and boys complete free

basic education .... and achieve relevant learning outcomes' (Target 2), '... youth and adults reach a proficiency level in literacy and numeracy ...' (Target 3 ), '... youth and adults have knowledge and skills for decent work and life ...' (Target 4), '... learners acquire knowledge, skills, values and attitudes to establish sustainable and peaceful societies ...' (Target 5). See Table 1 for a full list of these targets.

Several aspects of how learning is concretised in the targets of the Muscat GEM agreement and the position paper merit close attention.

First, Target 6 of the position paper, which focuses on NonFormal Education (NFE) and informal learning, is subsequently dropped in the Muscat GEM agreement. Furthermore, the integration of separate targets for upper secondary and tertiary education from the position paper into a more expansive target suggests that the broader lifelong learning framework has been considerably narrowed. Whether this reflects a desire for a more pragmatic and feasible agenda or is symptomatic of the multiple and sometimes competing discourses is a question which requires more careful scrutiny.

Second, while there is a clear acknowledgement of the complexity and the constraints associated with measurement in the position paper, reflected as 'Policy imperatives should drive measurement, not vice versa' and the call for review and development of new indicators (UNESCO, 2014a: 4), the targets constrain a broader conceptualisation of quality. In spite of this qualification in the position paper, Target 1 learning outcomes are specified as 'relevant and measurable learning outcomes based on national standards' (UNESCO, 2014a: 5). While the term 'measurable' is dropped from the corresponding target in the Muscat GEM agreement, the vision still emphasises 'measurable global targets'. Furthermore, in both the position paper and the Muscat GEM agreement, literacy and numeracy are seen as essential to participation in society; in fact, the statement 'other basic skills' present in Target 4 in the position paper (UNESCO, 2014a: 6) is dropped from the corresponding target in the Muscat GEM agreement. These changes, along with the clear specifications for proficiency in numeracy and literacy, suggest an unfolding of the quality agenda as a 'literacy and numeracy' agenda rather than demonstrating a commitment to a more holistic vision of quality. Moreover, it appears that a concern with measurement might drive and govern the vision of quality, reducing it to an outcome-focused, literacy and numeracy agenda (cf. Sayed and Sprague, 2013; Barrett, 2013; Nikel and Lowe, 2010; Tikly and Barrett, 2009).

Third, the narrowing of the quality and learning agenda is again evident in the targets relating to global citizenship and sustainable development. Leaving them vague and unspecified, as they have been, risks delegitimising them and relegating them to a priority of low importance. As Alexander (2014) has pointed out, children's development of the skills and values of global citizenship and sustainable development may be less easily amenable to quantitative measurement than literacy and numeracy. However, excluding them from the specifics of policy operationalisation notably delimits the holistic vision of 'quality' education as a lever of social justice and social transformation, articulated as being a key EFA principle and goal. Their absence indicates an as-yetunresolved challenge in relation to developing targets that incorporate qualitative indicators to meaningfully reflect achievement in learning areas related to responsible global citizenship, peace and sustainable development (Alexander, 2014).

Fourth, while it is helpful to consider different learning outcomes for early and late learning and incorporating different levels of education, the targets and the thematic areas in the position paper and the Muscat GEM agreement reinforce the idea that early learning is reducible to literacy and numeracy and later learning is synonymous with skills for work distinction. King and Palmer (2013) suggest that the learning and skills for work distinction are not helpful if confined to certain groups, and that this perspective makes it difficult for work and life to be part of a holistic vision of education and lifelong learning. Preparation for life and work is integral to all learning, implying that other knowledge, values and skills are as essential as literacy and numeracy at any phase of lifelong learning. Development priorities like employment are important in shaping the education agenda, but should not determine it.

Finally, while there is arguably a possible narrowing in the conceptualisation of learning, it is noteworthy that the Muscat GEM agreement, unlike the position paper, seeks to operationalise 'equity' in relation to learning by the addition of the phrase '... particular attention to gender equality and the most marginalised' in Targets 1, 2, 3 and 4. It suggests that one of the big shifts in the targets is the narrowing of the learning agenda, with a foregrounding of the equity agenda. This inclusion emphasises the 'equity as quality' agenda and signals the need to develop indicators for equity. While this is welcome, whether equity should be a separate target or integrated into learning targets is still open to debate. The addition of a target date for the Muscat GEM agreement is important, though, interestingly, no mention is made of intervening targets periods as suggested in the thematic consultations (UNESCO and UNICEF, 2013).

\section{Education quality and teachers in the policy texts}

The focus on quality in the post-2015 agenda rightly emphasises a concern with teachers, teaching and teacher education. The policy recommendations in the UNESCO Position Paper on Education post-2015 (UNESCO, 2014a) suggest a range of key aspects regarding teachers including ‘a) recruiting and 
retaining well-trained and motivated teachers who use inclusive, gender-responsive, and participatory pedagogical approaches to ensure effective learning outcomes, b) providing content that is relevant to all learners and to the context in which they live, c) establishing learning environments that are safe, gender-responsive, inclusive and conducive to learning, and encompass mother tongue-based multilingual education, d) ensuring that learners reach sufficient levels of knowledge and competencies according to national standards at each level, e) strengthening capacities for learners to be innovative and creative, and to assimilate change in their society and the workplace and over their lifespans, and f) strengthening the ways education contributes to peace, responsible citizenship, sustainable development and intercultural dialogue' (UNESCO, 2014a: 8). The translation of this ambition is reflected in Targets 7 and 8 of the position paper and Targets 5 and 6 of the Muscat GEM agreement.

The more expansive ambition for teachers in the initial position paper gives way to a narrower construction of teachers focused on '... qualified, professionally trained, motivated, and well supported teachers' (UNESCO, 2014b: 3) with a specific target date inserted. The narrowed construction discounts the earlier discussion of a focus on pedagogy, where it is argued that there is a need to close the teacher gaps and for teachers who can '... deliver relevant content with emphasis on gender balance' (UNESCO, 2014a: 8). The apparent narrower construction in the Muscat GEM agreement potentially excludes pedagogy and equity issues. The task of improving the quality of teaching and learning and characterising the 'quality' teacher requires closer attention than the documents provide. 'Teacher quality' is meaningless without a clear understanding of what pedagogical processes are generative of quality learning and how teacher agency, and therefore teacher quality, can enact them.

An important omission in the construction of the targets is the lack of a robust focus on equity. The key issue is not that all learners should be taught by qualified, professionally trained, motivated, and well-supported teachers, but how to get such teachers in hardto-reach areas. In South Africa for example, the inequities in education and the existence of two systems of education (Sayed, 2014) can partly be attributed to the fact that good teachers working in an enabling learning environment are clustered in the wealthier school sector which, when added to the cultural capital of learners, creates a double privilege (Sayed, 2014). To overcome inequities in South Africa would require positive discrimination in favour of learners in disadvantaged contexts through the distribution and payment of teachers. Moreover, it is not clear why, if equity and social justice are key goals underpinning the teacher targets, more attention is not paid to attracting the best candidates to teach from diverse and under-represented groups, including female teachers, as the initial goals in the position paper suggested.

The focus on teachers in the post-2015 agenda resonates with evidence suggesting that teachers, teaching and teacher education make a difference. Perhaps the most cited 'research' is that of the McKinsey 2010 report (Mourshed et al., 2010). Amongst the recipes it provides for education improvement is the oftrepeated dictum that no country and education rises above the level of its teachers. The report argues that world-class education systems 'get the right people to become teachers, and develop them into effective instructors to ensure that the system delivers the best possible instruction for every child'. The Deputy President of South Africa, Cyril Ramaphosa, cited the study, arguing that teachers needed to be approached as the 'solution to the current crisis in education and not the problem', and that South Africa needed teachers that had 'the ability and commitment to nurture and develop young people to their full potential' (City Press, 9th August 2014).
While the evidence makes it clear that teachers matter, it is less clear which processes pertinent to teacher quality explain the difference in student outcomes. Thus, the existing research does not clearly indicate what it is that matters about teachers and teaching. ${ }^{8}$ As Alexander $(2014: 4,7)$ states:

.. the task of improving the quality of teaching and learning requires closer attention to the description and analysis of quality (Alexander, 2014: 4) ... the correlation between teaching quality and learning outcomes is self-evident and empirically demonstrated. But what should teachers teach and how? And on what aspects of their teaching should their training concentrate, and why? And can we answer these questions if the nature of teaching has been inadequately conceived? (Alexander, 2014: 7).

Targets about teachers are not very helpful without a contextualised and clear understanding of what pedagogical processes are generative of quality learning and how teacher agency can enact them. A contextualised reading of teacher agency is crucial, as Fenstermacher and Richardson (2005: 205, cited in Naylor and Sayed, 2014) note:

There is currently a considerable focus on quality teaching, much of it rooted in the presumption that the improvement of teaching is a key element in improving student learning. We believe that this policy focus rests on a naive conception of the relationship between teaching and learning. This conception treats the relationship as a straightforward causal connection, such that it could be effective, it could be sustained under almost any condition, including poverty, vast linguistic, racial or cultural differences...

While it is important to place teachers at the heart of the post2015 agenda, there is a danger that this positioning will become part of a narrow school effectiveness discourse linked to managerialist and regulatory interventions. This would reduce the agency of teachers to an audit trail and underplay teachers' enactment of generating learning in classrooms with pupils (Robertson, 2012). Certainly, one of the concerns about the narrower construction in the Muscat GEM agreement is the extent to which reforms about teacher education could be interpreted within this discourse. One important change is that the position paper seems to recognise that teachers form part of a broader learning environment, specified as 'supported by safe, genderresponsive learning environments' in Target 8 (UNESCO, 2014a: 8 ), whereas this relationship is less clear in the Muscat GEM agreement.

Conceptualisations of teacher pedagogy and agency in any future education agenda need to recognise that teaching in an inherently evaluative and value-driven activity. Fenstermacher and Richardson (2005) consider good teaching in relation to the worthiness of the activity. Teaching is thus not only about student outcomes, but is also about teaching as a moral activity. Thus, the post-2015 education agenda should envelop a vision of teachers, teaching, and teacher education which foregrounds the values of social justice and equity.

Of particular concern in the discourse of teachers in the post2015 agenda is that a vast and broad range of expectation and knowledge are expected of teachers - life skills, citizenship and peace education, moral and ethical education, child protection, human rights, skills for sustainable livelihoods, challenging gender

\footnotetext{
8 Other than the McKinsey report, several research studies and meta-analyses or single country quantitative and quantitative studies of successful student outcomes from a range of contexts attempt to identify the impact of teacher quality on student outcomes and the factors of teacher quality that make a difference, including subject knowledge, professional development and classroom practices. (.)
} 
inequalities, practising learner-centeredness (Sinclair, 2002; UNESCO-IIEP, 2006: 2,3) to name but a few. While these are important concerns, such an ambitious variety of responsibilities runs the real risk of overstating the potential of schools and their teachers to effect broad social transformations. It is sobering to note that, in a survey of ten countries, only $23 \%$ of teachers thought they had influence over policy and practice (UNESCO, 2014c). Teacher agency, as envisaged in the post-2015 agenda, is not a realistic possibility nor is agency possible when faced with multiple and conflicting demands subject to narrow accountability measures.

The inclusion of teachers in the post-2015 agenda will require increased and more strategic investments in education. It will also require rethinking the macroeconomic models that structure teacher salaries in low-income countries (ActionAid, 2007). This is why the targets on aid in the position paper (Target 9) and the Muscat GEM Agreement (Target 7) are welcome. One of the differences between the position paper and the Muscat GEM agreement is that whereas the aid target is fixed in the former $(6 \%$ of GNP and $20 \%$ of education budget), the latter favours a range with the previous fixed targets being the maximum (4-6\% of GNP and $15-20 \%$ of education budget). In addition, there is an omission of the specification of donor funding in the Muscat GEM Agreement. Importantly, the reference to innovative and increased funding' present in the position paper is not included in the Muscat GEM agreement. Furthermore, an important slippage is that the unit of the aid target shifts from groups to countries in that the position paper states '... prioritizing groups most in need' while the Muscat GEM agreement states '... prioritizing countries most in need'. This slippage runs the risk of ignoring the fact that inequality is as much within as between countries; therefore aid must target both countries and groups most in need. Finally, no mention is made of better pay for teachers, a priority in many countries with the biggest education challenges (UNESCO, 2014c).

\section{Conclusion}

The language of these documents and much of the discourse about the post-2015 agenda is, at one level, both a list of needed items and a 'to-do' list. King and Palmer (2013) refer to this situation as presenting more ideas and 'must-haves' than concrete, evidence-based suggestions. There is a real risk that the agenda remains a heady declaration of a list of aspirations (Tomlinson and Benefield, 2005: 17, 18) not supported by a firm evidence base. The danger of the vision articulated for the post-2015 education agenda is that it could mean all things to all people. The future challenge is to clearly define this vision. The on-going consultations and efforts to engage with the evidence should help.

The broad and extensive consultation process that has been part of this policy conversation needs to continue, as substantive participation is central to the ownership of the post-2015 education agenda. In particular, consultation with teachers and their representatives is essential for any post-2015 agenda that has quality teaching and learning at its heart.

Several implications for the post-2015 education agenda emerge from the analysis of the UNESCO-driven consultations about EFA. First, a tension clearly exists between process and outcomes (Barrett, 2013) and the extent to which the quality agenda is still being shaped by what can be easily measured. A broader conceptualisation of learning is required, rather than one that assumes that the focus should be on measurable outcomes for a narrow range of basic skills in literacy and numeracy. Whilst global targets and measures which set minimum benchmarks may be important for accountability purposes, there is a real risk that this may narrow the education quality agenda. It is imperative that what is measured as learning is comprehensive and does not delegitimise important aims of education such as citizenship.

Second, analysis of the targets suggests that there is a need to balance the setting of ambitious targets that may not be reached, with narrower but more achievable targets, especially in light of the unfinished agenda. But such a balance should not result in a narrow education agenda which focuses on low-hanging fruits, measuring what can be conveniently measured. The post-2015 education agenda provides an important space to develop an approach to education quality which can result in a more expansive conceptualisation of learning.

Third, the post-2015 education agenda, whilst containing a welcome target on teachers that represents, at some level, a substantive advance in the current global education discourse, needs to pay more attention to teacher pedagogy. Dynamic process-oriented models of teaching and learning, the continued foregrounding of pedagogy, and substantive engagement with diversity and context are just some of the processes that will impact on a target for teachers. Unless this occurs, merely increasing the supply of teachers, as the OWG Outcomes document suggests, will not necessarily promote effective teaching and learning.

Like all policy texts, the multiple and competing discourses present in the UNESCO documents generate both richness and contradictions. Some of the changes made to the targets, such as those regarding the financing of education from the UNESCO position paper to the Muscat GEM agreement, point to both the complexity and contestation in policy formulation. It is imperative that quality for the post-2015 agenda continues to be framed as the search for social justice and moves beyond a simplistic inputoutput model characteristic of human capital approaches.

\section{References}

ActionAid, 2007. Confronting the Contradictions: The IMF, Wage Bill Caps and the Case for Teachers. Action Aid, London.

Alexander, R., 2014. Teaching and learning for development: the 2013/14 education for all global monitoring report. In: Paper presented at the Conference organised by the Norwegian National Commission for UNESCO Norad, the Norwegian Refugee Council and the University of Oslo, Oslo, 3 February 2014.

Barrett, A., Chawla-Duggan, R., Lowe, J., Nikel, J., Ukpo, E., 2006. The Concept of Quality in Education: A Review of the 'International' Literature on the Concept of Quality in Education, vol. 2. EdQual, , pp. 1-19.

Barrett, A., 2013. Measuring Learning Post-2015. University of Oxford. The 12th UKFIET International Conference on Education and Development (unpublished manuscript, work in progress).

City Press, 2014. Teachers Are the Solution, not the Problem - Interview with Cyril Ramaphosa. Available from: http://www.citypress.co.za/news/ teachers-solution-problem-cyril-ramaphosa/ (accessed 25.08.14).

Engelbrecht, P., Green, L., 2001. Promoting Learner Development: Preventing and Working with Barriers to Learning. Van Schaik Publishers, Pretoria.

Espinoza, O., 2008. Solving the equity-equality conceptual dilemma: a new model for analysis of the educational process. Educ. Res. 49 (4), 343-363. Available from: http://www.tandfonline.com/doi/abs/10.1080/00131880701717198\#. U_usj0vA0ds (accessed 25.08.14).

Fenstermacher, G.D., Richardson, V., 2005. On making determinations of quality in teaching. Teach. Coll. Rec. 107 (1), 186-213. Available from: http://www. tcrecord.org/content.asp? contentid=11694 (accessed 25.08.14).

Jones, T., 2013. Understanding Education Policy: The Four Policy Orientations. Springer, New York.

King, K., 2013a. Education and development in the post-2015 landscapes forward Norrag News, 49, pp. 1-2. Available from: http://www.norrag.org/en/ publications/norrag-news/online-version/education-and-developmentin-the-post-2015-landscapes.html (accessed 25.08.14)

King, K., 2013b. Education and development in the post-2015 landscapes network for international policies and cooperation in education and trainingIn: Norrag Policy Brief.

King, K., Palmer, R., 2013. Post-2015 agendas: Northern tsunami, southern ripple? The case of education and skills. Int. J. Educ. Dev. 33, 409-425. Available from: http://www.sciencedirect.com/science/article/pii/S0738059313000643 (accessed 25.08.14)

Mourshed, M., Chijioke, C., Barber, M., 2010. How the World's Most Improved School Systems Keep Getting Better. McKinsey \& Company. Available from: http:// mckinseyonsociety.com/ how-the-worlds-most-improved-school-systems-keep-getting-better (accessed 25.08.14) 
My World, 2013. Listening to 1 Million Voices. Available from: http://www.odi.org/ sites/odi.org.uk/files/odi-assets/publications-opinion-files/8580.pdf (accessed 28.08.14).

Naylor, R., Sayed, Y., 2014. A Review of the Literature on Teacher Quality (unpublished mimeo).

Nikel, J., Lowe, J., 2010. Talking of fabric: a multi-dimensional model of quality in education. Compare 40 (5), 589-605.

Rizvi, F., 2006. Imagination and the globalization of educational policy research. Glob. Soc. Educ. 4 (2), 193-205.

Robertson, S., 2012. Placing teachers in global governance agendas. Comp. Educ. Rev. 56 (4), 584-607.

Sayed, Y., 1997. The concept of quality in education: a view from South Africa. In: Watson, K., Modgil, S., Modgil, C. (Eds.), Educational Dilemmas: Debate and Diversity, vol. 4. Cassell, London.

Sayed, Y., 2013. Post 2015 Education and Development Agenda. Background Research Paper for UNESCO and UNICEF consultations (unpublished mimeo).

Sayed, Y., 2014. The semi-privatization of public schooling in post-apartheid South Africa: securing elitism or the seeds of radical change? Paper presented at Social Policy Association Social Policy confronting Change: Resistance, Resilience Conference, 14-16 July 2014, Sheffield, University of Sheffield.

Sayed, Y., Ahmed, R., 2011. Education quality in post apartheid South African policy: balancing equity, diversity, rights and participation. Comp. Educ. 47 (1), 103-118.

Sayed, Y., Soudien, C., 2003. (Re) Framing education exlusion and inclusion discourses: limits and possibilities. IDS Bull. 34 (1), 9-19. Available from: http:// onlinelibrary.wiley.com/doi/10.1111/j. 1759-5436.2003.tb00055.x/abstract (accessed 28.08.14).

Sayed, Y., Sprague, T., 2013. Post-2015 education and development - contestation contradictions and consensus. Special Issue of the compare forum on education and development post 2015. Compare 43 (6)

Sinclair, M., 2002. Planning Education in and after Emergencies. UNESCO, International Institute for Educational Planning, Paris.

Tikly, L., Barrett, A., 2009. Social justice, capabilities and the quality of education in low income countriesIn: EdQual, Working Paper 18.

Tomlinson, K., Benefield, P., 2005. Education and Conflict: Research and Research Possibilities. National Foundation for Educational Research, UK.

UN High Level Panel, 2013. A New Global Partnership: Eradicate Poverty and Transform Economies through Sustainable Development. UN, New York.
Available from: http://www.post2015hlp.org/wp-content/uploads/2013/05/ UN-Report.pdf (accessed 25.08.14).

UNDG (United Nations Development Group), 2015. A Million Voices: The World We Want: A Sustainable Future with Dignity for All. UN, New York. Available from: http://www.worldwewant2015.org/millionvoices.

UN Open Working Group on Sustainable Development, 2014. Outcomes Document UN, New York. Available from: http://sustainabledevelopment.un.org/index. php?.menu=1561.

Proposed Goals and Targets on Sustainable Development. UN, New York. Available from: http://sustainabledevelopment.un.org/content/documents/4523 zerodraft.pdf

UNESCO and UNICEF, 2013. Making Education a Priority in the Post-2015 Development Agenda: Report of the Global Thematic Consultation on Education in the Post-2015 Development Agenda. UNESCO, Paris. Available from: http://www. unesco.org/new/en/media-services/single-view/news/making_education_a_ priority_in_the_post_2015_development_agenda_new_report/\#.U_uVkvA0du (accessed 28.08.14).

UNESCO, 2000. Dakar Framework for Action: Education for All Meeting our Collective Commitments. UNESCO, Paris. Available from: http://unesdoc.unesco.org/ images/0012/001211/121147e.pdf (accessed 25.08.14).

UNESCO, 2005. EFA Global Monitoring Report 2004/2005: Education for All: The Quality Imperative. UNESCO, Paris. Available from: http://www.unesco.org/ new/en/education/themes/leading-the-international-agenda/efareport/ reports/2005-quality/

UNESCO-IIEP, 2006. Guidebook for Planning Education in Emergencies and Reconstruction. UNESCO International Institute of Educational Planning, Paris.

UNESCO, 2014a. Position Paper on Education Post-2015. Post 2015 United Nations Development Agenda; EFA: Education for All. ED-14/EFA/POST-2015/1.

UNESCO, 2014b. 2014 GEM Final Statement: The Muscat Agreement. EFA: Education for All: Muscat Agreement. Global Education for All Meeting. ED-14/EFA/ $\mathrm{ME} / 3$ REV.

UNESCO, 2014c. EFA Global Monitoring Report 2013/4: Teaching and Learning: Achieving Quality for All. UNESCO, Paris.

UNESCO, 2014d. Addressing Exclusion. Available from: http://www.unesco.org/ new/en/education/themes/strengthening-education-systems/inclusiveeducation/ (accessed 25.08.14) 